\title{
Total synthesis of the protected aglycon of fidaxomicin (Tiacumicin B, Lipiarmycin A3)
}

\author{
Miyatake-Ondozabal, Hideki ; Kaufmann, Elias ; Gademann, Karl
}

\begin{abstract}
Fidaxomicin, also known as tiacumicin B or lipiarmycin A3, is a novel macrocyclic antibiotic that is used in hospitals for the treatment of Clostridium difficile infections. This natural product has also been shown to have excellent bactericidal activity against multidrug-resistant Mycobacterium tuberculosis. In spite of its attractive biological activity, no total synthesis has been reported to date. The enantioselective synthesis of the central 18-membered macrolactone is reported herein. The key reactions include ring-closing metathesis between a terminal olefin and a dienoate moiety for macrocyclization, a vinylogous Mukaiyama aldol reaction, and a Stille coupling reaction of sterically demanding substrates. The retrosynthesis involves three medium-sized fragments, thus leading to a flexible yet convergent synthetic route.
\end{abstract}

DOI: https://doi.org/10.1002/anie.201409464

Posted at the Zurich Open Repository and Archive, University of Zurich ZORA URL: https://doi.org/10.5167/uzh-138850

Journal Article

Accepted Version

Originally published at:

Miyatake-Ondozabal, Hideki; Kaufmann, Elias; Gademann, Karl (2015). Total synthesis of the protected aglycon of fidaxomicin (Tiacumicin B, Lipiarmycin A3). Angewandte Chemie Internationale Edition, 54(6):1933-1936.

DOI: https://doi.org/10.1002/anie.201409464 


\title{
Total Synthesis of the Protected Aglycon of Fidaxomicin (Tiacumicin B, Lipiarmycin A3)
}

\author{
Hideki Miyatake-Ondozabal, Elias Kaufmann and Karl Gademann*
}

Dedication ((optional))

\begin{abstract}
Fidaxomicin, also known as tiacumicin B or lipiarmycin A3, is a novel macrocyclic antibiotic used in hospitals for the treatment of Clostridium difficile infections. This natural product has also been shown to have an excellent bactericidal activity against multi-drug resistant Mycobacterium tuberculosis. In spite of its attractive biological activity, no total synthesis has ever been reported to date. Herein, we report the enantioselective synthesis of the central 18membered macrolactone. The noteworthy reactions include ringclosing metathesis between a terminal olefin and a dienoate moiety for macrocyclization, a vinylogous Mukaiyama aldol reaction, and a Stille coupling reaction of sterically demanding substrates. The retrosynthesis comprises of three medium sized fragments leading to a flexible yet convergent synthetic route.
\end{abstract}

Among all the treatable diseases, tuberculosis (TB) still remains one of the major public health concerns worldwide. ${ }^{[1]}$ Approximately nine million new cases of TB and an estimated two million deaths occur each year. ${ }^{[2]}$ Current therapeutic options, such as the use of frontline drugs (rifampicin and isoniazid), have become limited due to the spread of resistant forms of bacteria. ${ }^{[3]}$ Hence, the development of new anti-Mycobacterium tuberculosis pharmaceuticals has become an urgent task in the present medical research. In this context we became interested in fidaxomicin (1, tiacumicin B, lipiarmycin $A 3),{ }^{[4]}$ which is a bacterial RNA polymerase inhibitor with promising anti-bacterial activity against MTB. ${ }^{[1]}$ The molecule is also structurally attractive, owning a complex 18-membered aglycon fragment with multiple stereogenic centers, two glycosidic linkages where the eastern glycoside carries a fully substituted dichlororesorcinol unit. Unfortunately, the lack of bioavailability and vulnerability of the compound under acidic conditions prohibited its use as a therapeutic for TB. ${ }^{[5]}$ Structure modifications either by semi- or total synthesis could therefore be crucial operation to improve its pharmacokinetic profile.

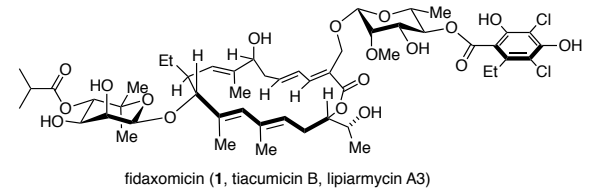

Currently, this natural product is used in the clinic for the treatment of a different disease, namely Clostridium difficile

[] Dr. H. Miyatake-Ondozabal, E. Kaufmann, Prof. Dr. K. Gademann Department of Chemistry, University of Basel St. Johanns-Ring 19, 4056 Basel (Switzerland)

E-mail: karl.gademann@unibas.ch

Homepage: http://www.chemie.unibas.ch/ gademann

${ }^{[* *} \quad$ We gratefully acknowledge partial financial support by the Latsis Prize (to K.G.), and the Novartis Early Career Award (to K.G.). We thank Christian Fischer for skillful technical support, Priv.-Doz. Dr. D. Häussinger for assistance with NMR spectroscopy, and Dr. M. Neuburger for X-ray crystallographic analysis. This publication is partially supported by the Swiss National Science Foundation as part of the NCCR Molecular Systems Engineering.

Supporting information for this article is available on the WWW infections, and introduced on the market by Optimer pharmaceuticals in 2011. ${ }^{[6]}$ Fidaxomicin has demonstrated similar clinical cure rates compared to vancomycin, however it is considered to be superior due to its favorable adverse effect profile (decreased rates of recurrence). Given its proven potential as a pharmaceutical, we started to investigate an efficient and convergent total synthesis of fidaxomicin (1) and thereby allowing access to structurally diverse analogues with appropriate pharmacokinetics for the treatment of TB. It is remarkable that no total synthesis has been reported to date since its first isolation via fermentation of a strain called Actinoplanes deccanensis in 1975, and despite its clinical use as a pharmaceutical agent. ${ }^{[7]}$ Up to now, synthetic studies of the core aglycon have been documented in a PhD thesis, ${ }^{[8]}$ and studies on the carbohydrates, ${ }^{[9,10]}$ and resorcinol ${ }^{[11]}$ parts have been reported in the literature. Independent and concomitant syntheses of the lipiarmycin A3 macrolactone and a putative lipiarmycin aglycon have been carried out by the groups of Altmann and Zhu, respectively. ${ }^{[12]}$
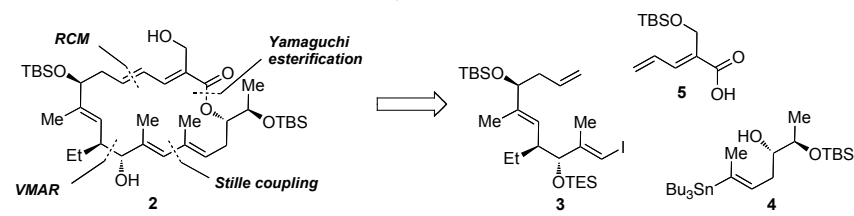

Scheme 1. Proposed retrosynthesis of the target macrolactone 2.

In this communication, we report the successful synthesis of the central aglycon of fidaxomicin (1) featuring a vinylogous Mukaiyama aldol reaction (VMAR), a Stille coupling reaction, Yamaguchi esterification, and a ring-closing metathesis (RCM). We have established a relatively short and highly convergent synthetic route to the macrocycle 2 where our retrosynthetic analysis led to three main building blocks, the vinyl iodide 3 , the vinyl stannane $\mathbf{4}$ and the dienoic acid $\mathbf{5}$ (Scheme 1).

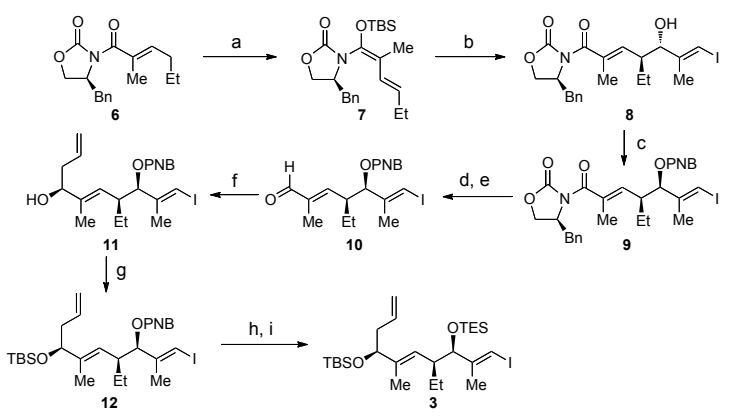

Scheme 2. Synthesis of vinyl iodide fragment 3. a) NaHMDS, THF, $-78^{\circ} \mathrm{C}$ then TBSCl, 97\%; b) (E)-3-iodo-2-methylacrylaldehyde, $\mathrm{TiCl}_{4}, \mathrm{CH}_{2} \mathrm{Cl}_{2},-78^{\circ} \mathrm{C}$ to $-30^{\circ} \mathrm{C}, 47 \%$, d.r. $>20: 1$; c) para-nitrobenzoic acid, $\mathrm{DEAD}, \mathrm{PPh}_{3}, \mathrm{THF}$, $0^{\circ} \mathrm{C}, 78 \%$; d) $\mathrm{NaBH}_{4}, \mathrm{THF} / \mathrm{H}_{2} \mathrm{O}$; e) $\mathrm{MnO}_{2}, \mathrm{CH}_{2} \mathrm{Cl}_{2}, 76 \%$ (2 steps); f) (-)$\mathrm{Ipc}_{2} \mathrm{~B}$ (allyl), $\mathrm{Et}_{2} \mathrm{O},-78^{\circ} \mathrm{C}$ then aq. $\mathrm{NaBO}_{3}, 70 \%$, d.r. $\left.=20: 1 ; \mathrm{g}\right)$ TBSOTf, 2,6lutidine, $\mathrm{CH}_{2} \mathrm{Cl}_{2}, 93 \%$; h) $\mathrm{K}_{2} \mathrm{CO}_{3}, \mathrm{MeOH} / \mathrm{H}_{2} \mathrm{O}$; i) TESOTf, 2,6-lutidine, $\mathrm{CH}_{2} \mathrm{Cl}_{2}$, 95\% (2 steps). DEAD: diethyl azodicarboxylate, HMDS:

hexamethyldisilazane, Ipc: isopinocampheyl, PNB: para-nitrobenzyl, TBS: tert-butyldimethylsilyl, TES: triethylsilyl, THF: tetrahydrofuran. 
The synthesis started with the preparation of silyl ketene $\mathrm{N}, \mathrm{O}$ acetal 7 via $\gamma$-deprotonation and O-tert-butyldimethylsilylation of the known building block 6 (Scheme 2). ${ }^{[13]}$ The subsequent antiselective $\mathrm{VMAR}^{[14]}$ was performed between 7 and freshly prepared $(E)$-3-iodo-2-methylacrylaldehyde in the presence of $\mathrm{TiCl}_{4}$ as a Lewis acid. In search of the best reaction conditions, we found that a higher reaction concentration led to highest yield and diastereoselectivity $(47 \%$, d.r. $>20: 1)$ with $35 \%$ recovery of desilylated starting material 6 . To the best of our knowledge, this transformation represents the first example of a VMAR, developed by Kobayashi et al., ${ }^{[14]}$ where a different substituent (ethyl group in our case) has been utilized as opposed to the standard methyl group. In order to obtain the desired synconfigured product, a Mitsunobu inversion was carried out to give ester 9 in $78 \%$ yield. ${ }^{[15]}$ The selective cleavage of Evans auxiliary ${ }^{[16 a]}$ over the PNB-ester was achieved under reducing conditions ${ }^{[16 \mathrm{~b}]}$ and the subsequent allylic oxidation with $\mathrm{MnO}_{2}$ gave the $\alpha, \beta$-unsaturated aldehyde 10 in $76 \%$ yield over two steps. The absolute configuration of the product was unambiguously confirmed by a single crystal $X$-ray crystallographic analysis of its vinyl bromide derivative. The next step involved a diastereoselective Brown allylation of aldehyde 10 with (-)-allyl-diisopinocampheylborane. ${ }^{[17]}$ A high diastereoselectivity of 20:1 was observed along with acceptable yield of $70 \%$. The TBS-protection of the allylic alcohol 11 furnished silyl-ether 12 (93\%). Subsequent exchange of the protecting groups from benzoylester to silylether (95\% over two steps) turned out to be an essential manipulation to accomplish the successful cross-coupling reaction.

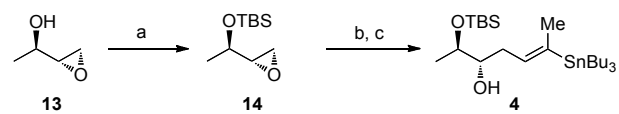

Scheme 3. Synthesis of vinyl stannane fragment 4. a) TBSCl, Imid, $\mathrm{CH}_{2} \mathrm{Cl}_{2}$, $93 \%$; b) propyne, $n$-BuLi, $\mathrm{BF}_{3} \cdot \mathrm{Et}_{2} \mathrm{O}, \mathrm{THF},-78^{\circ} \mathrm{C}$ to $0^{\circ} \mathrm{C}, 90 \%$; c) $\mathrm{Pd}(\mathrm{OAc})_{2}$, $\mathrm{PCy}_{3}, \mathrm{Bu}_{3} \mathrm{SnH}$, hexane, 51\%. Imid: imidazole, Cy: cyclohexyl.

The southern building block of the macrolactone was prepared in three synthetic steps (Scheme 3). The synthesis began with a silyl-etherification ${ }^{[18]}$ of a known chiral epoxy alcohol 13 (93\%, e.e. $>99: 1$ ), accessible via a kinetic resolution of 3-buten-2-ol using Sharpless epoxidation. ${ }^{[19]}$ Regioselective epoxide opening ${ }^{[20]}$ using propynyllithium and boron trifluoride diethyl etherate was followed by $\mathrm{Pd}$-catalyzed hydrostannylation to give the secondary alcohol 4 in $46 \%$ yield over two steps. During the course of hydrostannlylation, the formation of undesired regioisomer could not be supressed, thus leading to only moderate yield. Other approaches such as hydrozirconation ${ }^{[21]}$ and stannylcupration $^{[22]}$ gave complex mixtures of products.

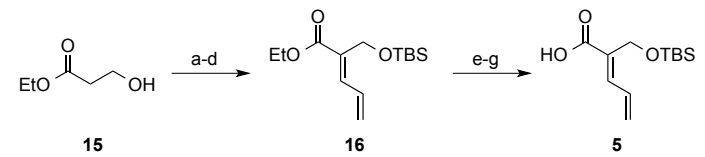

Scheme 4. Synthesis of dienoic acid fragment 5. a) LDA (3.5 equiv), THF, $-78^{\circ} \mathrm{C}$ then acrolein, $-78^{\circ} \mathrm{C}$; b) $\mathrm{Me}_{2} \mathrm{SnCl}_{2}$ (10 mol\%), $\mathrm{TBSCl}, \mathrm{Et}_{3} \mathrm{~N}, 75 \%$ (2 steps); c) $\mathrm{Ac}_{2} \mathrm{O}, \mathrm{Et}_{3} \mathrm{~N}, \mathrm{DMAP}, \mathrm{CH}_{2} \mathrm{Cl}_{2}$; d) DBU, $\mathrm{CH}_{2} \mathrm{Cl}_{2}, 72 \%$ (2 steps), $E: Z=$ 5.5:1; e) DIBAH, $\mathrm{CH}_{2} \mathrm{Cl}_{2},-10^{\circ} \mathrm{C}$; f) $\mathrm{MnO}_{2}, \mathrm{CH}_{2} \mathrm{Cl}_{2}$; g) $\mathrm{NaClO}_{2}, \mathrm{KH}_{2} \mathrm{PO}_{4}$, 2methyl-2-butene, $t$ - $\mathrm{BuOH} / \mathrm{H}_{2} \mathrm{O}, 70 \%$ (3 steps). LDA: lithium diisopropylamide, DBU: 1,8-diazabicycloundec-7-ene, DIBAH: diisobutylaluminium hydride, DMAP: 4-dimethylaminopyridine.
The final building block 5 constitutes for the eastern part of the macrolactone, incorporating the dienoic acid moiety (Scheme 4). Firstly, commercially available ethyl 3-hydroxypropanoate (15) was treated with excess of lithium diisopropylamide and reacted with acrolein to furnish the corresponding aldol product. Next, the mono-selective tert-butyldimethylsilylation mediated by dimethyltin dichloride ${ }^{[23]}$ was followed by acetylation and base induced $E_{1 c b}$-elimination to give the dienoate 16 in $54 \%$ over four steps $(d . r .=5.5: 1)$. Finally, formal hydrolysis (DIBAH reduction, allylic and Lindgren-Pinnick oxidations) of ester $\mathbf{1 6}$ was executed to give the corresponding carboxylic acid $\mathbf{5}$ in $70 \%$ yield over three steps. It is worth mentioning that the standard hydrolysis conditions using either lithium hydroxide or sodium hydroxide led to desilylation as a major side reaction.

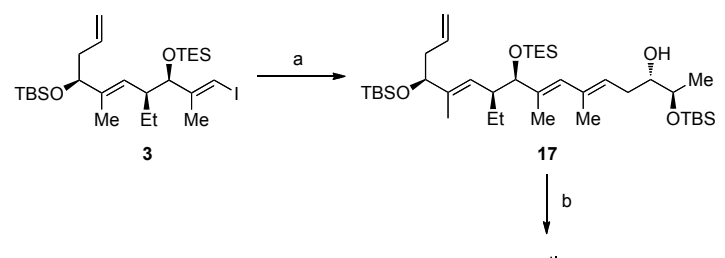

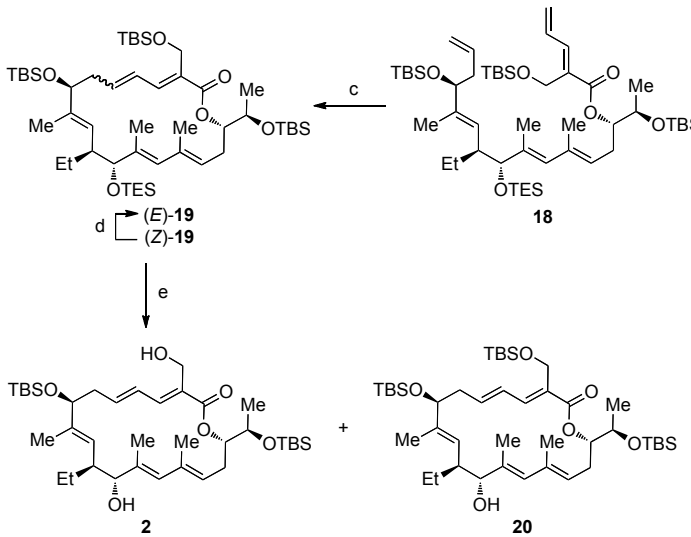

Scheme 5. Synthesis of bis-silyl protected aglycon 2. a) 4, CuTC, $\mathrm{Pd}\left[\mathrm{PPh}_{3}\right]_{4}$, $\left[\mathrm{Bu}_{4} \mathrm{~N}^{+}\left[\mathrm{Ph}_{2} \mathrm{PO}_{2}\right]\right.$, DMF, 77\%; b) 5, $\mathrm{Cl}_{3} \mathrm{C}_{6} \mathrm{H}_{2} \mathrm{COCl}, \mathrm{Et}_{3} \mathrm{~N}, \mathrm{DMAP}, \mathrm{PhMe}, 86 \%$; c) Grubbs cat. II (15 mol\%), PhMe, $40^{\circ} \mathrm{C}(\mu \mathrm{w}), 10 \mathrm{~min}, E: Z=2: 3$, then $100^{\circ} \mathrm{C}$, $18 \mathrm{~h}, E: Z=2: 1,90 \%$; d) Grubbs cat. II (15 mol\%), PhMe, $100^{\circ} \mathrm{C}, 18 \mathrm{~h}, E: Z=$ $2: 1,92 \%$; e) HF.Et ${ }_{3} \mathrm{~N}, \mathrm{THF} / \mathrm{MeCN} 1: 1,0^{\circ} \mathrm{C}$ to $23^{\circ} \mathrm{C}, \mathbf{2}: 65 \%, 20: 32 \%$. CuTC: copper(I) thiophene-2-carboxylate, DMF: dimethylformamide.

With the three building blocks $\mathbf{3}, \mathbf{4}$ and $\mathbf{5}$ in hand, we focused our attention to the Stille coupling step. As anticipated, this transformation was experimentally challenging due to the sterically damanding nature of both vinyl iodide and stannane fragments. After screening of several reaction conditions, we were delighted to find the optimal conditions using a combination of copper thiophene-2-carboxylate (CuTC) ${ }^{[24]}$ and $\left[\mathrm{Pd}\left(\mathrm{PPh}_{3}\right)_{4}\right]$ in the presence of tetrabutylammonium diphenylphosphonate salt, ${ }^{[25]}$ giving the diene $\mathbf{1 7}$ in very high yield of $77 \%$ (Scheme 5). In this step, the only significant side reaction was the selfdimerization of the vinyl iodide $3(\sim 10 \%)$. These unique yet effective conditions have been reported by Fürstner and coworkers and a series of hindered substrates have been successfully cross-coupled. ${ }^{[26]}$ The resulting secondary alcohol 17 was then efficiently acylated with dienoic acid $\mathbf{5}$ under Yamaguchi esterification ${ }^{[27]}$ conditions to give ester 18 in $86 \%$ yield. Pleasingly, the subsequent $\mathrm{RCM}^{[28]}$ of olefin 18 proceeded smoothly utilizing the second generation Grubbs catalyst (15 mol\%) to give a mixture of $E: Z$ macrocycles in a overall yield of $90 \%$. Both the initiation and conversion of this transformation 
could be observed to be extremely fast and it could be conducted even at room temperature, intriguingly giving only the $Z$-isomer 19 in this case. At $40^{\circ} \mathrm{C}$, full conversion was observed within 10 minutes with $E: Z$ ratio of $2: 3$ and further improvement to ratio of 2:1 was possible through isomerization at elevated temperature. Interestingly the fact that the isomerization was not observed in the absence of the catalyst, the thermodynamic equilibrium is most likely reached through ring-opening and closing events. Fortunately, the two isomers were separable by column chromatography, which in turn allowed recycling of Zisomer to isomerization conditions giving $80 \%$ yield of $E$-isomer 19 after one cycle. The final selective deprotection of primary TBS-ether and secondary TES-ether were achieved using triethylamine trihydrofluoride in $65 \%$ yield. In order to avoid unwanted over-deprotection, the reaction had to be stopped after a certain time allowing the isolation of TES-ether deprotected intermediate 20 (32\%), which could be recycled to give more of the desired diol $\mathbf{2}$. The aglycon $\mathbf{2}$ fulfills the criteria as a key building block for the completion of the total synthesis, having the appropriate free hydroxyl groups for the following glycosylations.

In summary, we report the preparation of the protected aglycon of fidaxomicin (1). The target macrocycle 2 was successfully synthesized in 14 steps (longest linear sequence) through three main fragments, allowing considerable amount of flexibility in exploring the points of diversity for analogue synthesis. The highlights of our strategy include the RCM between a terminal olefin and a dienoate moiety for macrocyclization, a diastereoselective VMAR, and a Stille coupling reaction of sterically hindered substrates. Currently, the total synthesis of the natural product including the preparations of noviose, rhamnose, and resorcinol units as well as glycosylation studies are in progress in our group and will be reported in due course.

Keywords: Natural products • antibiotics $•$ cross coupling • stereoselective synthesis

[1] M. Kurabachew, S. H. J. Lu, P. Krastel, E. K. Schmitt, B. L. Suresh, A. Goh, J. E. Knox, N. L. Ma, J. Jiricek, D. Beer, M. Cynamon, F. P. V. Dartois, T. Keller, T. Dick, V. K. Sambandamurthy, J. Antimicrob. Chemother. 2008, 62, 713-719.

[2] M. Zignol, M. S. Hosseini, A. Wright, C. L. Weezenbeek, P. Nunn, C. J. Watt, B. G. Williams, C. Dye, J. Infect. Dis. 2006, 194, 479-485.

[3] A. Tupin, M. Gualtieri, J.-P. Leonetti, K. Brodolin, The EMBO Journal, 2010, 29, 2527-2537.

[4] For an excellent review on the chemistry and biology of tiacumicin since their discovery, see: W. Erb, J. Zhu, Nat. Prod. Rep. 2013, 30, 161-174. For the identity of lipiarmycin A3 and tiacumicin B, see A. Bedeschi, P. Fonte, G. Fronza, C. Fuganti, S. Serra, Nat. Prod. Commun. 2014, 9 , 237-240.

[5] K. Traynor, Am. J. Health Sys. Pharm. 2011, 68, 1276-1277.

[6] A. A. Venugopal, S. Johnson, Clin. Infect. Dis. 2012, 54, 568-574.

[7] a) F. Parenti, H. Pagani, G. Beretta, J. Antibiot. 1975, 28, 247-252; b) C. Coronelli, J. R. White, C. G. Lancini, F. Parenti, J. Antibiot. 1975, 28 , 253-259; c) C. Coronelli, F. Parenti, R. White, H. Pagani, GB 1458512 , 1973, Gruppo Lepetit.

[8] W. Erb (2010). Approche vers la synthese totale de la lipiarmycine A3. Ph.D. Thesis. University of Paris-Sud XI, France.

[9] For previous synthesis of 2-O-methyl-D-rhamnose, see: a) A Lipták, Carbohydr. Res. 1982, 107, 300-302; b) A. Lipták, I. Czégény, J Harangi, P. Nánási, Carbohydr. Res. 1970, 73, 327-331.

[10] For previous synthetic studies on noviose, see: a) A. Klemer, M. Waldmann, Liebigs Ann. Chem. 1986, 2, 221-225; b) E. Walton, US
2938900, 1960, Merck \& Co

[11] For previous synthesis of resorcylic acid, see: a) M. Alexy, H.-D. Scharf, H.-D. Liebigs Ann. Chem. 1991, 1363-1364.

[12] a) F. Glaus, K.-H. Altmann, Angew. Chem. Int. Ed., 2014, accepted; b) W. Erb, J.-M. Grassot, D. Linder, L. Neuville, J. Zhu, Angew. Chem. Int. Ed. 2014, accepted.

[13] a) K. Ohata, S. Terashima, Chem. Pharm. Bull. 2009, 57, 920-936; b) D. J. Ager, D. R. Allen, D. R. Schaad, Synthesis 1996, 1283-1285.

[14] a) S. Shirokawa, M. Kamiyama, T. Nakamura, M. Okada, A. Nakazaki, S. Hosokawa, S. Kobayashi, J. Am. Chem. Soc. 2004, 126, 1360413605. For applications of this methodology to the synthesis of natural products, see: b) S. Hosokawa, T. Ogura, H. Togashi, K. Tatsuta, Tetrahedron Lett. 2005, 46, 333-337; c) K. Tatsuta, S. Hosokawa, Chem. Rev. 2005, 105, 4707-4729; d) M. Yamaoka, A. Nakazaki, S. Kobayashi, Tetrahedron Lett. 2010, 51, 287-289; e) A. Schmauder, L. Sibley, M. E. Maier, Chem. Eur. J. 2010, 16, 4328-4336; f) I. Paterson, J. S. B. Kan, J. Gibson, Org. Lett. 2010, 12, 3724-3727; g) R. Matsui, K Seto, Y. Sato, T. Suzuki, A. Nakazaki, S. Kobayashi, Angew. Chem. Int. Ed. 2011, 50, 680-683; Angew. Chem. 2011, 123, 706-709; h) K. Fujita R. Matsui, T. Suzuki, S. Kobayashi, Angew. Chem., Int. Ed. 2012, 51, 7271-7274. For a recent review on VMAR in natural product synthesis, see: M. Kalesse, M. Cordes, G.

Symkenberg, H.-H. Lu, Nat. Prod. Rep. 2014, 31, 563-594.

[15] For an example of Mitsunobu reaction carried out on a similar substrate, see: K. Kobayashi, Y. Fujii, I. Hayakawa, H. Kigoshi, Org. Lett. 2011, 13, 900-903.

[16] a) J. R. Gage, D. A. Evans, Org. Synth. 1990, 68, 77-80; b) A. Schmauder, S. Müller, M. E. Maier, Tetrahedron 2008, 64, 62636269.

[17] a) H. C. Brown, M. C. Desai, K. P. Jadhav, J. Org. Chem. 1982, 47, 5065-5069; b) H. C. Brown, B. Singaram, J. Org. Chem. 1984, 49, 945947; c) H. C. Brown, K. S. Bhat, R. S. Randad, J. Org. Chem. 1987, 52, 319-320; d) H. C. Brown, K. S. Bhat, R. S. Randad, J. Org. Chem. 1989, 54, 1570-1576; e) U. S. Racherla, H. C. Brown, J. Org. Chem. 1991, 56, 401-404. For applications of Brown allylation to similar substrates, see: f) K. C. Nicolaou, Y. He, F. Roschangar, N. P. King, D. Vourloumis, T. Li, Angew. Chem. Int. Ed. 1998, 37, 84-87; Angew. Chem. 1998, 110, 2120-2153; g) J. A. Lafontaine, D. P. Provencal, C. Gardelli, J. W. Leahy, J. Org. Chem. 2003, 68, 4215-4234; h) P. V. Ramachandran, T. E. Burghardt, M. V. R. Reddy, J. Org. Chem. 2005, 70, 2329-2331.

[18] R. M. Hindupur, B. Panicker, M. Valluri, M. A. Avery, Tetrahedron Lett. 2001, 42, 7341-7344

[19] a) J. D. White, M. Kang, B. G. Sheldon, Tetrahedron Lett. 1983, 24, 4539-4542; b) X. Li, U. H. Manjunatha, M. B. Goodwin, J. E. Knox, C. A. Lipinski, T. H. Keller, C. E. Barry, C. S. Dowd, Bioorg. Med. Chem. Lett. 2008, 18, 2256-2262.

[20] For examples of similar epoxide opening reactions, see: a) K. C. O'Brien, E. A. Colby, T. F. Jamison, Tetrahedron 2005, 61, 6243-6248; b) S. Hayashi, K. Hirano, H. Yorimitsu, K. Oshima, J. Am. Chem. Soc. 2008, 130, 5048-5049.

[21] For examples of hydrostannylation reactions, see: a) I, Shiina, $\mathrm{H}$. Oshiumi, M. Hashizume, Y. Yamai, R. Ibuka, Tetrahedron Lett. 2004, 45, 543-547; b) M. Kalesse, M. Quitschalle, C. P. Khandavalli, A. Saeed, Org Lett. 2001, 3, 3107-3109; c) P. T. O'Sullivan, W. Buhr, M. A. M. Fuhry, J. R. Harrison, J. E. Davies, N. Feeder, D. R. Marshall, J. W. Burton, A. B. Holmes, J. Am. Chem. Soc. 2004, 126, 2194-2207; d) F. Song, S. Fidanze, A. B. Benowitz, Y. Kishi, Tetrahedron 2007, 63, 5739-5753.

[22] J.-F. Betzer, F. Delaloge, B. Muller, A. Pancrazi, J. Prunet, J. Org. Chem. 1997, 62, 7768-7780

[23] T. Takeichi, M. Kuriyama, O. Onomura, Tetrahedron Lett. 2011, 52 6646-6648.

[24] G. D. Allred, L. S. Liebeskind, J. Am. Chem. Soc. 1996, 118, 27482749.

[25] a) J. Srogl, G. D. Allred, L. S. Liebeskind, J. Am. Chem. Soc. 1997, 119, 12376-12377; b) A. B. Smith, K. P. Minbiole, P. R. Verhoest, M. Schelhaas, J. Am. Chem. Soc. 2001, 123, 10942-10953; c) T. B. Durham, N. Blanchard, B. M. Savall, N. A. Powel, W. R. Roush, J. Am. Chem. Soc. 2004, 126, 9307-9317.

[26] a) A. Fürstner, C. Nevado, M. Tremblay, C. Chevrier, F. Teplý, C. Aïssa, 
WILEY-VCH

M. Waser, Angew. Chem. Int. Ed. 2006, 45, 5837-5842; Angew. Chem 2006, 118, 5969-5974; b) A. Fürstner, C. Nevado, M. Waser, M.

Tremblay, C. Chevrier, F. Teplý, C. Aïssa, E. Moulin, O. Müller, J. Am Chem. Soc. 2007, 129, 9150-9161; c) A. Fürstner, J.-A. Funel, M. Tremblay, L. C. Bouchez, C. Nevado, M. Waser, J. Ackerstaff, C. C. Stimson, Chem. Commun. 2008, 2873-2875; d) A. Fürstner, J. Ackerstaff, Chem. Commun. 2008, 2870-2872; e) A. Fürstner, C. L. Bouchez, L. Morency, J.-A. Funel, V. Liepins, F.-H. Porèe, R. Gilmour, D. Laurich, F. Beaufils, M. Tamiya, Chem. Eur. J. 2009, 15, 3983-4010.

[27] N. M. Ahmad in Yamaguchi esterification. In Name Reactions for
Functional Group Transformations; J. J. Li, E. J. Corey, Eds.; John Wiley \& Sons: Hoboken, NJ, 2007, pp 545-550.

[28] For applications of RCM for macrocyclisation in natural product synthesis, see reviews by: a) K. C. Nicolaou, P. G. Bulger, D. Sarlah, Angew. Chem. Int. Ed. 2005, 44, 4490-4527; Angew. Chem. 2005, 117, 4564-4601; b) A. Gradillas, J. Pérez-Castells, Angew. Chem. Int. Ed. 2006, 45, 6086-6101; Angew. Chem. 2006, 118, 6232-6247. For an example of similar RCM in total synthesis, see: S. Barluenga, P. Lopez, E. Moulin, N. Winssinger, Angew. Chem. Int. Ed. 2004, 43, 2367-2370. 


\section{Entry for the Table of Contents}

\section{COMMUNICATION}

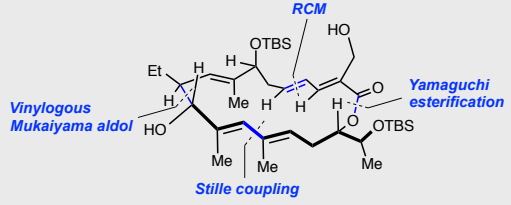

The core aglycon of the clinically used antibiotic fidaxomicin was synthesized utilizing ring-closing metathesis for macrocyclization. This synthetic route is highly convergent highlighting the use of diastereoselective vinylogous Mukaiyama aldol reaction of a novel substrate, Yamaguchi esterification as well as a Stille coupling reaction between two sterically hindered intermediates.
Hideki Miyatake-Ondozabal, Elias

Kaufmann, Karl Gademann*

Page No. - Page No.

Total Synthesis of the Protected Aglycon of Fidaxomicin (Tiacumicin B, Lipiarmycin A3) 